\title{
REGIONAL DEVELOPMENT IN THE WESTERN BALKANS THROUGH THE SUPPORT OF EU PROJECTS
}

The paper shows how different support programs intended for institutions and organizations contribute to regional development and cooperation between the countries of the Western Balkans, as well as to higher economic development and prosperity of the region. Unfavourable economic and financial situation in most of the countries needs to be managed more efficiently through external financial support, which usually, in the case of the Western Balkans implies different EU programs. Such programs include the assistance in applying for CBC programmes, which further results in the development of the regional competitiveness through the implementation of joint projects. Such programs (CARDS 2000-2006, IPA 2007-2013 RSEDP2, IPA II 2014-2020) provide the financial support of the EU to resolve the issues of common interest (socio-economic, cultural and historical potentials) for neighbouring countries. The support programs should improve the institutional capacity of Serbia and strengthen the cooperation with the countries of the Western Balkans, which simultaneously implies alignment with European Structural Funds Regulations.

Keywords: Regional development, EU programs, Western Balkan countries

\footnotetext{
* Associate Professor, Graduate School of Business Studies, University "John Naisbitt", Belgrade e-mail: atosovic@naisbitt.edu.rs

** Associate Professor, Faculty of Business Economics and Entrepreneurship, Belgrade e-mail: vmristanovic@gmail.com
} 


\section{Introduction}

One of the main objectives of the regional policy of the European Union is to contribute to the regional development, networking and cooperation of the countries in order to reduce economic and social differences between the member states on the one hand, but on the other hand to encourage their economic development and prosperity. EU regional policy is the most important instrument for achieving so-called cohesion and involves adjusting to new trends, and large-scale restructuring (infrastructure development, reducing unemployment, stimulating industry and all forms of business activities) in order to enhance the competitiveness of local economy and thus equalize differences in the development of EU regions (Mirić, 2009).

Since the creation of the European Economic Community (EEC) in 1958, the regional policy has had several stages (http://www.regionalnirazvoj.gov.rs/):

- The first one remained from 1958 to 1975 and its main feature was insufficiently focused approach to regional policy of the Community.

- The essential features of the second stage (1975-1986) were the creation of new instruments and strengthening of the existing ones, as well as a small but constant growth of available funds.

- The third stage was from 1986 to 1999 . The main feature of the phase is reforming and increasing available funds, as well as improving the efficiency of the used instruments and resources.

- The fourth stage represents the period from 2000 to 2006. In this phase, the Agenda 2000 was prepared, which envisaged the biggest enlargement of the EU (May 2004), under which 10 countries became EU member states. The enlargement increased the population of the EU by $20 \%$ and gross domestic product (GDP) by only $5 \%$.

- The fifth stage covers the current budget period from 2007 to 2013. It is characterized by the biggest established amount of the funds intended for the poorest member states and regions and the focus is on faster economic growth, job creation and innovation.

Considering that EU emphasises regional cooperation as a key factor for economic development and prosperity of the countries, as well as political stability and security, the aim of this paper is to examine how various support programs intended for institutions and organizations contribute to regional development and cooperation between the countries of the Western Balkans.

For the Republic of Serbia, as a candidate for the membership in the EU, regional cooperation should not only be a formal precondition for the EU accession process, but the real indicator of the country's commitment to regional cooperation. Regional cooperation can be analysed through three components: economic (trade liberalization, improving the business environment, etc.), safety 
(especially important for the Western Balkans) and political components (closely connected with the two previously mentioned ones).

In order to provide fast and sustainable economic growth and development, it is essential to consider both social and economic benefits, but also to identify shortcomings and weaknesses. Primarily, one of the most serious problems is the fact that the Republic of Serbia lags behind EU standards in a number of aspects (the average GDP per capita, unemployment, infrastructure ...). Additionally, there is uneven development of individual territories. It is clearly seen between the underdeveloped (rural, mountain and border areas) and developed areas of the Republic of Serbia, which directly affect and result in undesirable economic, social and demographic consequences. The importance of the issue is furthermore stressed in the Constitution - "The Republic of Serbia develops balanced and sustainable regional growth in accordance with the law" (article 94 - Balancing development), and article 97 which states that the jurisdiction of the Republic Serbia is to regulate and ensure "the development of the Republic of Serbia, policy and measures for boosting balanced development of particular areas of the Republic of Serbia, including the development of underdeveloped areas as well; organization and the use of area; scientific and technological development" (paragraph 12 of the Constitution).

The problem of underdeveloped areas as well as critical review of the current policy of regional development, are presented in the adopted Strategy of regional development for the period 2007-2012 and Strategy of regional development of the Republic of Serbia. In 2009, according to the Law on Regional Development, a new framework and improved regional development policy of the Republic of Serbia was created. Essentially, at the beginning of EU accession process, the obligation was to create a legal framework in which this could be implemented, as well as to handle the issue of available incentive mechanisms, such as pre-accession funds (IPA), grant development assistance from the international community and other international sources of aid, which are in accordance with the law.

\section{EU support programs}

In order to support and strengthen the cooperation between the countries of the Western Balkans and the EU member states, based on the experiences of the countries that have become the EU member states, participation in EU support programs has turned out not only as a great strategy for the EU accession process, but also as a great contribution to the economic and political progress of the countries that use them.

The significant role of EU regional policy towards the Western Balkans in terms of region stability and their individual joining the EU, has been confirmed through the Stabilisation and Association Process, which was particularly emphasised at the EU summit in Thessaloniki in 2003. 
During the process of harmonization with the general European standards and norms, the Western Balkan countries are facing a number of common problems (the return of refugees, infrastructure reconstruction, economic development and organized crime...) as well as cross-border issue (http://www.regionalnirazvoj.gov.rs). Therefore, the EU encouraged the countries of the region to promote regional cooperation by the implementation of Neighbourhood programs and cross-border cooperation program (INTERREG - Interregional cooperation).

Cross-border cooperation has two modalities. The first one is the cooperation with the member states and the other one cooperation between the countries of the Western Balkans. The modalities differ according to the rules of project implementation. The CBC program, which is implemented between EU member states and candidate countries in the budget period 2007-2013, implies using also the funds intended for potential project applicants. The financial resources for the member states are taken from the European Regional Development Fund (ERDF). The financial resources for the program participants who are candidate countries are provided from other components - the Instrument for Pre-Accession Assistance (http://www.regionalnirazvoj.gov.rs).

The Instrument for Pre-Accession Assistance (IPA) combines all the programs to assist the countries wishing to join the EU and has two main aims: to assist beneficiary countries in meeting the political, economic and criteria relating to the Adoption of the Acquis, and the other one is to build administrative capacity and strengthen the judiciary and preparation process for the use of structural and cohesion funds after the EU accession (http://europa.rs/).

Community Assistance for Reconstruction, Development and Stabilisation (CARDS) is the EU program, also designed for the Western Balkan countries, which was in the stabilization and association process. The program was used in the period from 2000 to 2006 to develop institutions and legislation, sustainable economic and social development, regional and cross-border cooperation among the countries of the Western Balkans and the EU member states.

Regional Socio-Economic Development Programme (RDEPR 2) is the EU technical assistance program aimed at supporting regional development agencies in the Republic of Serbia. Technical assistance consists of four key components: the support to regional development agencies and local and regional participants, inter-municipal cooperation, learning and support to the Grant Scheme (http:// www.regionalnirazvoj.gov.rs/).

In addition to the support programs of the EU, this paper is going to present other financial EU programs in which the Republic of Serbia participates (Bass, Knezević, Dragojlović, 2014):

- Horizon 2020 / Horizon 2020 is a new EU program for research and innovation. The program is an instrument for achieving the main goals of the Europe 2020 strategy, and above all its Innovation Union initiative. 
- The Programme for the Competitiveness of Enterprises and SMEs / COSME - COSME aims to encourage competitiveness and sustainability of entrepreneurship in the EU, in particular small and medium-sized enterprises, as well as entrepreneurial culture support and the promotion of creativity and the development of SMEs.

- Employment and Social Innovation Programme EaSI / The programme aims to support social policy and employment policy in the EU. The program supports the efforts of the member states in the design and implementation of social reforms and reforms in the field of employment at European, national, regional and local level through the identification, coordination, analysis and exchange of best practices.

- Erasmus+. Erasmus+ programme is aimed at highlighting the skills and employability, as well as the modernization of education, training and jobs for young people. Erasmus+ can help 4 million European students to obtain sufficient training, gain professional experience and volunteer abroad. Erasmus + supports transnational partnerships between education, training institutions and youth institutions and organizations in establishing co-operation in the world of education and work to bridge the gap regarding qualifications that Europe is facing. As for sports, basic projects and cross-border challenges such as the fight against match-fixing, doping, violence and racism are supported.

- Connecting Europe Facility (CEF) / Connecting Europe Facility supports the development of sustainably, effectively related trans-European networks (TEN) in the fields of energy, telecommunications and transport exceptional characteristics. CEF enables the construction of those projects. Without CEF contribution, it would not be possible to implement all the aformentined things. It also aims to minimize administrative barriers and maximize participating funds from the EU budget in order to promote synergies.

- Copernicus / Copernicus is a European system liable for observing the Earth. It is a civilian program focused on the needs of users, built on the existing national and European facilities. It provides regular observation and monitoring of the Earth's subsystems - the atmosphere, oceans, and continental surfaces and provides reliable and verified information to protect the environment and civil security. 


\section{Programs and development of the Western Balkans - analysis}

One of the major political and economic projects of the EU, as a strategic framework [European Parliament (Article 218 (6) TFEU and Article 49 TEU)] ${ }^{1}$, is the integration of the Western Balkan countries (WBC) ${ }^{2}$ in the EU, through the process of cooperation and support in order to ensure stability and development in the region. ${ }^{3}$ This is a remarkable project, which is politically and economically designed to ensure stability and development in the region.

The overall cooperation between the EU and the Western Balkan region is reflected through the following instruments: 1 . The Stabilisation and Association Process (SAP) - a strategic framework that supports the gradual rapprochement of the Western Balkans with the EU, and is based on bilateral contracts, financial assistance, political dialogue, trade relations and regional cooperation; 2 . The accession process - the candidate countries and potential candidate countries receive financial assistance to implement the necessary reforms and fulfil the Copenhagen political criteria; 3 . Regional cooperation - encourages countries in the region to cooperate in a wide range of areas; 4 . The visa-free regime - enables the citizens of the region to travel without visas in the Schengen area. The instruments imply the appropriate financing methods.

The approach, closely monitored by the EU, implies active defining of national development strategy, which would adequately combine the regional aspect with the EU regional policy. This allows more appropriate use of assistance from the Structural Funds, and the willingness of the other member states to allocate the funds for interregional redistribution as a support mechanism for alleviating the existing territorial differences and better utilization of development resources that can be used by entering the EU. Hence, it is essential that a country plans the national budget that should be regional and sector-oriented, in the sense that it contains priority classification and the measures for sectorial and regional implementation strategy, as well as funding resources. Therefore, there is a significant increase in funding sustainable development in this area from its own resources (and in accordance with the actual and available capabili-

$1 \quad$ In the preamble of the Treaty of Rome (1958) it is outlined that the EU Member States should "reduce the differences existing between the various regions and the backwardness of the less favoured regions."

2 Western Balkans include the candidate countries Albania, the Former Yugoslav Republic of Macedonia, Montenegro and Serbia, as well as potential candidate countries Bosnia and Herzegovina and Kosovo*. They all have the perspective of joining the European Union.

3 "In order to promote the overall harmonious development, the European community will develop and perform the activities that lead to strengthening its economic and social cohesion. The Community will in particular aim at reducing the disparities between regions and the backwardness of the less privileged regions, including rural areas" (Article 130a, the Single European Act, 1986)

$4 \quad$ Regional Development Strategy of the Republic of Serbia from 2007 to 2012, p. 75. 
ties), especially with the recovery of the economy and a greater degree of macroeconomic stability.

The main objective of all the Western Balkan countries is bilateral resolution of border disputes, signing and implementation of the Free Trade Agreement, establishing cooperation in the fields of energy, transport and other areas. The European Union monitors the process and makes sure it is conducted in accordance with the acquis and supports the association process through various programs.

EU assistance through the IPA program is designed as a unique and coherent assistance instrument, but the Regulation on the establishment of IPA ${ }^{5}$ makes a difference between the beneficiary countries, from the aspect of owning a decentralized system of funds (Turkey, Croatia, Montenegro and Macedonia through all 5 components) and not-decentralized system of funds (Serbia, Kosovo ${ }^{6}$, Bosnia and Herzegovina and Albania through the first two components). In this context, the assistance is provided through the components IPA 2007-2013: (1) Transition Assistance and Institution Building; (2) Cross-border cooperation, (3) Regional Development, (4) Human Resources Development and (5) Rural Development. The focus of the programme is to assist countries in meeting the political, economic, and criteria relating to the Adoption of the Acquis, as well as building of administrative capacity and strengthening the judiciary, as well as to prepare for the use of the structural and cohesion funds from the EU with full membership in the EU.

In order to provide the possibility of financing from pre-accession funds to the region (PHARE, ISPA, SAPARD and CARDS), by the European Council Regulation no. 1085/2006 from July 2006, a new pre-accession instrument (IPA - Instrument for Pre-accession Assistance ${ }^{7}$ ) was established. According to the National Strategy for Sustainable Development of Serbia " EU pre-accession assistance (IPA) are also largely directed towards sustainable development. The resources are mainly allocated to the projects supporting refugees and displaced persons, regional and social development projects, health care reform, reduction of greenhouse gas emissions from the power plant Nikola Tesla, etc. The total funds directed to sustainable development that had already been defined in the IPA 2007 amounted to EUR 71 million or about $40 \%$ of all the funds available from the IPA program. "For the period 2007-2013 the financial value of the IPA programs amounted to approximately EUR 11.468 billion, of which the Republic of Serbia received EUR 1.4 billion. During the period, the

http://www.esteri.it/mae/resource/doc/2015/02/reg_ec_718_2007.pdf

Resolution 1244

Serbia will be a beneficiary of the IPA program funds from 2007 until EU membership, on the basis of a decision of the Council in Brussels in June 2006. Link:http://europa.rs/ upload/documents/1_21020060731en00820093.pdf

$8 \quad$ National Strategy for Sustainable Development of Serbia, page 124. 
candidate countries (Croatia and Macedonia) had available funds for all five components from IPA, while potential candidates (Republic of Serbia, Montenegro, Bosnia and Herzegovina and Albania) had only two out of five components: (1) transition process support and institution-building in line with the acquis, and (2) regional and cross-border cooperation. ${ }^{9}$

Table 1: The allocation of IPA funds defined by Multi-annual indicative financial framework (MIFF), the Western Balkans, 2007-2013, million euros

\begin{tabular}{|l|r|r|r|r|r|r|r|}
\hline & 2007 & 2008 & 2009 & 2010 & 2011 & 2012 & 2013 \\
\hline Albania & 61.0 & 70.7 & 81.2 & 94.1 & 94.4 & 94.5 & 98.1 \\
\hline Bosnia \& Herzegovina & 62.1 & 74.8 & 89.1 & 105.3 & 107.4 & 107.8 & 111.8 \\
\hline Croatia & 141.2 & 146.0 & 151.2 & 153.5 & 156.5 & 156.1 & 95.4 \\
\hline The former Yugoslav Republic of Macedonia & 58.5 & 70.2 & 81.8 & 91.6 & 98.0 & 101.8 & 117.2 \\
\hline Kosovo* & 68.3 & 184.7 & 106.1 & 67.3 & 68.7 & 68.8 & 73.7 \\
\hline Montenegro & 31.4 & 32.6 & 34.5 & 33.5 & 34.1 & 35.0 & 35.4 \\
\hline Serbia & 189.7 & 190.9 & 194.8 & 197.9 & 201.8 & 202.0 & 214.7 \\
\hline
\end{tabular}

Source: EU Delegation in Serbia

Note: In addition to the Western Balkan countries, a large proportion is for Turkey, then to multi-beneficiary programs, and a small part for Island.

The EU determined the planning process of funding by a Multi-annual indicative financial framework (MIFF). Out of all the funds from the IPA preaccession assistance for the Western Balkan countries, excluding Turkey and Iceland, the majority of the funds was used for the programmes in the Republic of Serbia. It is more than $1 / 4$ of the total funds budgeted.

The idea of the second component of the IPA is to strengthen cross-border cooperation, create joint local and regional initiatives that aim to promote sustainable economic and social development in many areas, such as: environment, natural and cultural heritage, public health, prevention and the fight against organized crime, ensuring efficient and secure borders and the promotion of joint small-scale actions involving local participants from the border regions. The Republic of Serbia could use more than EUR 70 million through the projects (just below Croatia). ${ }^{10}$

In the Republic of Serbia, the basis of cooperation with the countries of the Western Balkans was set in implementation period of EU assistance under the CARDS programme (2000-2006). CARDS program dates back to 2000 from

9 The remaining three components are: (3) regional development - infrastructure investments; (4) human resources development; and (5) rural development. Serbia, although being a potential candidate country in 2009, began the preparations to use the remaining three components.

10 Serbia in the European integration process, Serbian European Movement 
the idea of support to the Western Balkans in the Stabilisation and Association Process (SAP). In the period 2000-2006, the program provided EUR 4.6 billion for the investment, institutional buildings and other measures. The main objectives of the program were: (1) democratic stability, (2) institutional and legislative development, (3) sustainable economic development and (4) improving the relations in the region. The entire program was conducted under the Economic Agency for Reconstruction (EAR), which was responsible for the program in the Republic of Serbia.

Realized CARDS programs in the Western Balkans contributed to: (1) the construction of institutions and improved legislation; (2) the development of a market economy, with the investment in vital physical infrastructure and a higher level of environmental protection, and (3) democratic stabilization, social development and strengthening of civil society. CARDS regional and national programmes were supplemented in the areas of institutional buildings, justice and internal affairs, environment protection, integrated border management, transport, civil society, etc.

According to data of the EAR, since 2000 when financial support to the Western Balkan region began, a lot of progress and success has been made.

Table 2: EAR funds, until July 2007

\begin{tabular}{|l|r|r|r|r|r|}
\hline & $\begin{array}{c}\text { Appropriated } \\
(1)\end{array}$ & $\begin{array}{c}\text { Contracted } \\
(2)\end{array}$ & \multicolumn{1}{c|}{$(2) /(1)$} & \multicolumn{1}{c|}{ Paid (3) } & \multicolumn{1}{c|}{$(3) /(1)$} \\
\hline Serbia & $1,3 \mathrm{mlrd} \mathrm{e}$ & $1,1 \mathrm{mlrd} \mathrm{e}$ & $87 \%$ & $921 \mathrm{mil} \mathrm{e}$ & $71 \%$ \\
\hline Montenegro & $130 \mathrm{mil} \mathrm{e}$ & $121 \mathrm{mil} \mathrm{e}$ & $93 \%$ & $104 \mathrm{mil} \mathrm{e}$ & $80 \%$ \\
\hline Kosovo* & $1,11 \mathrm{mlrd} \mathrm{e}$ & $1,07 \mathrm{mlrd} \mathrm{e}$ & $96 \%$ & $998 \mathrm{mil} \mathrm{e}$ & $90 \%$ \\
\hline The FYR of Macedonia & $327 \mathrm{mil} \mathrm{e}$ & $296 \mathrm{mil} \mathrm{e}$ & $91 \%$ & $259 \mathrm{mil} \mathrm{e}$ & $79 \%$ \\
\hline Total EAR & $2,86 \mathrm{mlrd} \mathrm{e}$ & $2,6 \mathrm{mlrd} \mathrm{e}$ & $91 \%$ & $2,3 \mathrm{mlrd} \mathrm{e}$ & $80 \%$ \\
\hline
\end{tabular}

Through these funds, the Republic of Serbia has managed to improve institutional capacities, agriculture, energy sector, health care, higher education facilities, as well as human rights.

Chronologically speaking, the Reconstruction Agency in Serbia started activities in December 2000 through emergency program (amounted to EUR 182 million). In 2001 (with EUR 193 million) there were a couple of mediumterm and long-term investments in the key sectors of energy, health, agriculture and entrepreneurship. Such support was deepened in 2002 (with EUR 168 million) through economic development, improving governance and legislation, including the projects for recovering weakened infrastructure, the support to small and medium-sized enterprises (SMEs), the help to the reforms and the support to independent media and civil society. In 2003 (EUR 216 million euros) the activity of support and improvement of public finance, justice and internal 
affairs and administrative decentralization was present. In the following two years 2004 (EUR 206 million) and 2005 (EUR 152 million) the stress was on the support to European integration, the harmonization of institutions and regulations with EU standards.

Serbia has participated in numerous projects of the Western Balkans Investment Framework (WBIF), which was launched in December 2009 as a regional tool for the expansion of the European Commission. It supports socio-economic development and EU accession across the Western Balkans by providing financial and technical support for strategic investments. The framework increases the capacity of the region for financing key infrastructure and priority investments in line with the priorities of the accession and improves overall coordination assistance. ${ }^{11}$ Since 2009, Serbia has been connected to the total of 34 projects (6 regional and 28 national). These projects were sector-focused on the transport sector, environment sector, company sector and energy sector.

Through the Western Balkans Investment Framework in 2012, further promotion of regional cooperation and reconciliation in the Western Balkans continued. In addition, the EU assists countries through advice policy and financial assistance and support to the investments essential for the boost of economy growth and job creation. In that year WBIF supported 137 projects with approved grants in the amount of EUR 237 million and the total investment value of EUR 13 billion. The grants were approved in the amount of EUR 54.8 million to Bosnia and Herzegovina, EUR 44 million to Albania, EUR 34.3 million to Serbia, 30 million to Kosovo*, EUR 16.9 million to Macedonia and EUR 15.1 million to Montenegro. The largest part is related to the energy sector (with $55 \%)$, followed by society and transport sector (17\%), environment sector (9\%) and private sector development (2\%). In addition, such projects benefited all the Western Balkan countries in the region with (49\%) - Bosnia and Herzegovina (16\%), Macedonia (9\%), Kosovo * (8\%), Serbia (6\%), Montenegro (2\%).

Slovak experience, after ten years in the EU, has shown that Slovak economy economically strengthened, but that the absorption capacity of EU funds is rather weak (until 2015 it spent about $60 \%$ of planned EU funds). The key benefit of the membership reflected in the reform of tax system administration, health care and pension system. It is similar with Hungary, which strengthened both economically and politically. Without financial support from the EU, these results would not have occurred. However, there is a problem in the distribution of EU structural funds. The Poles have gone furthest - economic development, unemployment decrease, standard quality improvement and the increase of social equality of the citizens, as well as the strengthening of Polish political influence in the EU. The outcome of these results lies in the creation of adequate administrative capacity, long-term strategic planning, accelerated export and successful cooperation.

2012 Annual Report, The Western Balkans Investment Framework, page 5. 
In addition to these programmes, it is necessary to mention the European Instrument for Democracy and Human Rights, Erasmus Mundus and Tempus programmes.

The Republic of Serbia in competitions through the European Instrument for Democracy and Human Rights (EIDHR) in the period 2005-2009 gained over EUR 50 million. The objective of the EIDHR programme is to strengthen the role of civil society in promoting human rights and democratic reforms, supporting efforts to prevent conflict and consolidate its participation and representation in politics.

The Erasmus Mundus programme is an important programme concerning the support to the cooperation and mobility in higher education by promoting high-quality European master and doctoral studies. The programme aims to improve the quality of higher education and intercultural understanding through the cooperation with partner countries, as well as a greater degree of regional cooperation in the field of higher education. Erasmus Mundus was in the first phase implemented in the period 2004-2008, while the second phase lasted from 2009 to 2013.

In addition to the aforementioned programs in the field of higher education, it is important to mention the Tempus programs, which date in the various forms from 1989, all the time aiming to provide assistance to partner countries in the non-imposed acceptance of the development trends of EU higher education, and which originate from the Lisbon agenda and the Bologna process. The last phase, Tempus IV was implemented in the period 2007-2013. One of the main goals of the program is to improve the higher education system and its correlation with the labour market, as well as build the capacity of higher education institutions that can maintain the continuous process of modernization and international cooperation. Tempus programmes have special domain in the area of the Western Balkans - not only through the process of cooperation, but also in customizing Lifelong learning programme.

All the activities in the EU have enabled the Republic of Serbia to be proud of successful analytical review (March 2015) of the acquis communautaire. Furthermore, it can be pleased with the progress in achieving legal and economic criteria, immense progress has been made due to the adoption of a comprehensive action plan. ${ }^{12}$

Serbia Report 2015, European Commission, 10.11.2015. pp. 72-73

Vol. 13, № 2, 2016: 175-188 


\section{Conclusion}

The aim of the regional approach, as a part of the integrated policy, is to promote peace, stability and sustainable development in the Western Balkans. Through the regional support programs, the EU is trying to simplify the access to loans by pooling and coordinating different sources of funding and technical assistance.

The idea of EU support programs is the improvement of regional and local networks of basic infrastructure (transport, energy and environment), including social infrastructure, as well as the support to the private sector, with more investment in health and education sectors. All the activities are organized to improve access to financing SMEs, encourage development of the local economy and regional risk-free capital market, and try to promote the access to finances through financial engineering instruments. The approach (establishing joint grant and the possibility of joint loans) is a good basis for further investment in the region in the coming years, and it enables rapid development of the economy.

The priority of the EU is the integration and maintenance of these regional support programmes. By raising the efficiency and flexibility, and through active regional stimulation of the others, first of all, neighbouring countries, the region would give a positive contribution to the overall EU market.

This kind of cooperation is of great interest to both the EU and the Western Balkans. This is a key factor for establishing political stability, security and economic prosperity of the region and it opens the perspective of integration of the Western Balkans into the EU. 


\section{Literature}

- Bass D., Knežević I., Dragojlović N. (2014) Vodič kroz programe Evropske unije 2014-2020, Evropski pokret u Srbiji, Beograd.

- COM(1999)235 final: COMMISSION OF THE EUROPEAN COMMUNITIES, Brussels, 26.05.1999.

- EU (2013) The European future of the Western Balkans: Thessaloniki@10 (2003-2013), Institute for Security Studies, European Union.

- Marinkovic, I and Dall, E. (2014) R\&D and Innovation in Western Balkans, Centre for Social Innovation, ZSI Austria.

- Mirić, O. (2009) Regionalna politika Evropske unije kao motor ekonomskog razvoja, Evropski pokret u Srbiji, Beograd.

- Nacionalna strategija održivog razvoja Srbije, Vlada Republike Srbije, Beograd 2008.

- Strategic Study on Social Economy Development in the Context of the South East Europe 2020 Strategy, Regional Cooperation Council, Belgrade, European Movement in Serbia 2015.

- Serbia Report 2015, European Commision, 10.11.2015.

- Srbija u procesu evropskih integracija, Evropski pokret Srbija, 2012

- Službeni glasnik Republike Srbije, Br 51, Beograd, 2009.

- Vodič kroz IPA II, Instrumenti za predpristupnu pomoć, Evropski pokret Srbija, 2014

- Vlada RS (2006) Strategiju regionalnog razvoja Republike Srbije za period od 2007. do 2012. godine, „Službeni glasnik RS”, br. 55/05 i 71/05 - ispravka.

- 2012 Annual Report, The Western Balkans Investment Framework

- http://www.rapp.gov.rs/media/strategije/STRATEGIJA_\%20PRRS.pdf (april 2016.)

- www.sllistbeograd.rs/documents/ustav_republike_srbije_lat.pdf (april 2016.)

- http://europa.rs/pomoc-republici-srbiji/

- www.regionalnirazvoj.gov.rs/Lat/showNARRFolder.aspx?mi=116; www. regionalnirazvoj.gov.rs/Lat/showNARRFolder.aspx?mi=157; (april 2016.) 
Dr Aleksandra Tošović-Stevanović, vanredni Profesor

Fakultet za poslovne studije, Univerzitet „Džon Nezbit”, Beograd

Dr Vladimir Ristanović, VANREdNi PROFEsor

Visoka škola za poslovnu ekonomiju i preduzetništvo, Beograd

\section{REGIONALNI RAZVOJ ZEMALJA ZAPADNOG BALKANA KROZ PODRŠKU PROJEKATA EU}

U ovom radu prikazaćemo na koji način različiti programi podrške institucijama i organizacijama doprinose regionalnom razvoju i saradnji zemalja Zapadnog Balkana $u$ cilju ekonomskog razvoja i prosperiteta ovog regiona. Nepovoljna ekonomska i finansijska situacija u većini ovih zemalja, upućuju na efikasnije korišćenje eksterne finansijske podrške, što najčešće, u regionu Zapadnog Balkana, predstavljaju različiti programi EU. Ovakvi programi podrazumevaju pomoć pri apliciranju za programe prekogranične saradnje, a u isto vreme jačaju regionalnu konkurentnost kroz realizaciju zajedničkih projekata. Cilj ovakvih programa (CARDS 2000-2006, IPA 2007-2013, RDEPR 2, IPA II 2014-2020) jeste finansijska podrška EU u rešavanju pitanja od zajedničkog interesa (društveno-ekonomskih, kulturnih $i$ istorijskih potencijala) susednih država. Prioritet EU, kroz regionalne programe podrške, je povezivanje i podržavanje regionalnih programa u celom regionu, jer podizanjem efikasnosti i fleksibilnosti, a kroz aktivno regionalno stimulisanje drugih, pre svih, susednih zemalja, ovaj region bi dao pozitivan doprinos zajedničkom tržištu EU, što omogučava/otvara perspektivu integracije zemalja Zapadnog Balkana u EU.

Ključne reči: Regionalni razvoj, EU programi, zemlje Zapadnog Balkana 